\title{
Predicting Covid-19 Vaccination Intention: The Role of Health Belief Model of Muslim Societies in Yogyakarta
}

\author{
Memprediksi Minat Vaksinasi Covid-19: Peran Model Kepercayaan Kesehatan \\ Masyarakat Muslim di Yogyakarta
}

\author{
Muhammad A. S. P. Erawan ${ }^{* 1}$, Zaid $^{2}$, Katon Pratondo $^{3}$, Ahdiana Y. Lestari $^{4}$ \\ 1, 2, 4 Bagian Hukum, Universitas Muhammadiyah Yogyakarta, Yogyakarta \\ ${ }^{3}$ Bagian Manajemen, Universitas Pembangunan Nasional Veteran Yogyakarta, Yogyakarta
}

DOI: 10.24252/al-sihah.v13i1.20647

Received: 15 April 2021 / In Reviewed: 18 May 2021 / Accepted: 26 June 2021 / Available online: 30 June 2021

(C) The Authors 2021. This is an open access article under the CC BY-NC-SA 4.0 license

\begin{abstract}
After implementing various policies to deal with covid-19, which were still considered ineffective, the Government of Indonesia is now trying to implement a mandatory vaccination policy for all of its citizens. However, the program's success depended on the perceptions and beliefs that developed in the community regarding the covid-19 vaccine itself. This study aimed to examine the Health Belief Model (HBM) effect using the variables of perceived susceptibility, severity, benefits, and barriers on covid-19 vaccination intention. By using a quantitative method that was cross-sectional and involving 452 respondents who were taken using the purposive sampling method. After being analyzed using Partial Least Square Structural Equation Modeling (PLS-SEM), the results of this study showed that perceived susceptibility, severity, and benefits had a positive influence on covid-19 vaccination intention. At the same time, the perceived barrier showed a negative effect. In the end, this study provided a theoretical model of HBM in predicting behavioral intention, which in turn, predicted behavior. On the other hand, this research also provided a starting point for research into the interest in vaccination against covid-19 in Indonesia.
\end{abstract}

\begin{abstract}
ABSTRAK
Setelah menerapkan berbagai macam kebijakan penanggulangan covid-19 yang dirasa masih belum efektif, Pemerintah Indonesia kini berupaya mewajibkan vaksinasi bagi seluruh warga negaranya. Namun keberhasilan program tersebut sangat bergantung pada persepsi dan keyakinan yang berkembang di tengah masyarakat terkait vaksin covid-19 itu sendiri. Penelitian ini bertujuan untuk menguji pengaruh health Belief Model (HBM) dengan menggunakan variabel-variabel kerentanan, keparahan, manfaat, dan hambatan yang dirasakan terhadap minat vaksinasi covid-19. Dengan menggunakan metode kuantitatif yang bersifat cross-sectional dan melibatkan 452 responden yang diambil dengan menggunakan metode purposive sampling, hasil penelitian ini setelah dianalisis dengan menggunakan Partial Least Square Structural Equation Modeling (PLS-SEM) menunjukkan bahwa baik kerentanan, keparahan, dan manfaat yang dirasakan keseluruhannya memiliki pengaruh yang positif terhadap minat vaksinasi covid-19. Sementara hambatan yang dirasakan menunjukkan pengaruh yang negatif. Pada akhirnya penelitian ini memberikan model teoritis dari HBM dalam memprediksi minat perilaku, yang pada gilirannya, akan memprediksi perilaku. Di sisi lain, penelitian ini juga sekaligus memberikan titik awal untuk penelitian minat vaksinasi covid-19 di Indonesia.
\end{abstract}

\section{GRAPHICAL ABSTRACT}

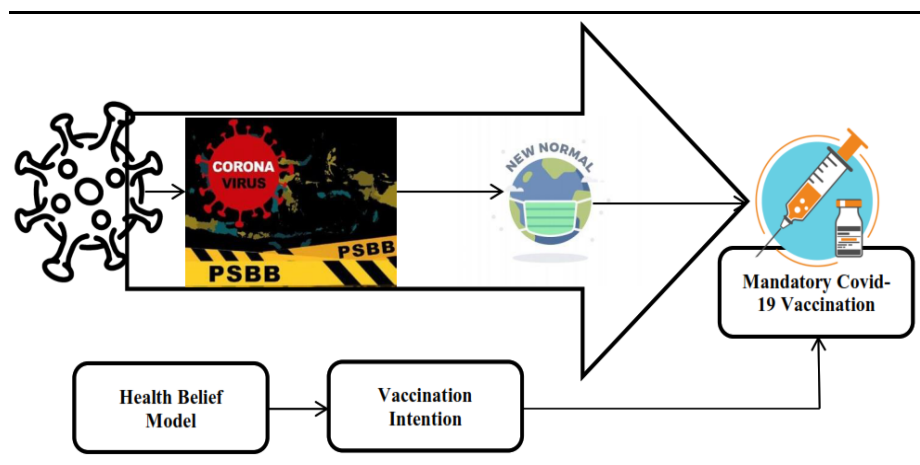

\section{Keyword}

perceived susceptibility; perceived severity; perceived benefit; perceived barriers

Kata Kunci:

hambatan dirasakan; keparahan dirasakan; kerentanan dirasakan; manfaat dirasakan

\section{* Correspondence}

J1. KH. Ali Maksum 8, Bantul, Yogjakarta, 55188

Email: m.aufar.psc20@mail.umy.ac.id 


\section{PENDAHULUAN}

Penyebaran cepat penyakit yang berawal dari patogen bernama severe acute respiratory syndrome coronavirus 2 (SARS -CoV-2 yang secara filogenetik mirip dengan SARS-CoV) (Guan et al., 2020) atau yang lebih dikenal luas dengan sebutan Coronavirus Disease 2019 (covid-19) ini sudah sangat membahayakan kesehatan dan menyebabkan keresahan publik (Dinleyici et al., 2021). Wabah ini jugalah yang telah menyebabkan meluasnya jarak sosial (social distancing) hingga penguncian penuh (lockdown) di hampir sebagian besar negara-negara di dunia (Lytras \& Tsiodras, 2021). Di Indonesia sendiri, sejak mulai diidentifikasi pada awal Maret 2020 lalu (Cahyadi \& Newsome, 2021). Pemerintah Indonesia secara sigap berusaha menerapkan beberapa strategi mulai dari Pembatasan Sosial Berskala Besar (PSBB) hingga berakhir pada adaptasi kebiasaan baru (new normal) (Rohadi et al., 2020). Namun dengan hasil yang masih belum signifikan terlebih lagi setelah kelonggaran masa PSBB, korban terinfeksi covid-19 terus meningkat di luar kendali (Pradana et al., 2020), dan berkaca pada data jumlah kasus positif covid-19 dengan pertumbuhan yang cukup menghawatirkan (Suwantika et al., 2020), maka ada kebutuhan mendesak untuk mengembangkan vaksin yang aman dan manjur agar berhasil mengelola pandemi covid-19 yang belum pernah terjadi sebelumnya ini (Bennet et al., 2020).

Vaksin adalah tonggak penting bagi peningkatan kesehatan masyarakat (Urias, 2017) dan idealnya berkontribusi secara efektif dan efisien terhadap penurunan yang kuat untuk penyakit menular yang dicegah dengan vaksinasi (Fogel \& Kusz, 2016; Zhang \& Fisk, 2021). Terlebih lagi disituasi seperti pandemi covid-19 seperti saat ini yang tidak ada obat profilaksis yang mujarab serta sedikitnya perawatan (Hodgson et al., 2021). Sehingga vaksinasi diharapkan menjadi strategi efektif dalam menghentikan wabah ini (Auslander et al., 2019). Saat ini, pengembangan vaksin untuk covid-19 terjadi dengan kecepatan yang belum pernah terjadi sebelumnya (Gurwith et al., 2020), dengan lebih dari 100 kandidat vaksin yang dikembangkan di seluruh dunia (Bennet et al., 2020). Tampaknya Pemerintah Indonesia melalui Peraturan Menteri Kesehatan Republik Indonesia Nomor 10 Tahun 2021 Tentang Pelaksanaan Vaksinasi Dalam Rangka Penanggulangan Pandemi Corona Virus Disease 2019 (covid -19), akan menempatkan semua taruhannya pada vaksin yang akan tersedia segera setelah Januari 2021 (Sparrow et al., 2020) serta menjanjikan total 180 juta vaksin yang akan tercapai pada Maret 2022 (Kusumaningrum et al., 2021).

Hanya saja keberhasilan program vaksinasi ini sangat bergantung pada persepsi dan keinginan dari masyarakat (Karlsson et al., 2021). Sayangnya, fakta terkait ketidakpercayaan yang meluas pada keamanan dan efektivitas vaksin secara global disertai protes di seluruh dunia untuk kebijakan jarak sosial covid-19 dan prospek vaksinasi massal telah terjadi (Paul et al., 2021). Hal ini tentu akan sangat sulit untuk menyukseskan program vaksinasi pemerintah dalam menanggulangi covid-19 di Indonesia. Karenanya, berangkat dari 
narasi yang ada pada literatur sebelumnya yang menyatakan bahwa penelitian perilaku yang lebih kuat sangat diperlukan terutama di negara-negara (seperti Indonesia) yang penelitiannya kurang teridentifikasi (Karafillakis \& Larson, 2017). Oleh karena itu penulis dalam penelitian ini berusaha dan bertujuan untuk meneliti terkait minat vaksin covid-19. Jika penelitianpenelitian yang ada sebelumnya hanya berfokus pada peran kepercayaan sosial (Liu \& Yang, 2020), religiusitas (Olagoke et al., 2021), personal informasi, dan media massa (Sengupta \& Wang, 2014), maka dalam penelitian ini Health Belief Model (HBM) yang memiliki empat konstruksi utama, yaitu kerentanan yang dirasakan, keparahan yang dirasakan, manfaat yang dirasakan, dan hambatan yang dirasakan (Alhalaseh et al., 2020; Araban et al., 2017; FathianDastgerdi et al., 2021; Shahrabani \& Benzion, 2012; Sulat et al., 2018) akan menjadi prediktor minat vaksinasi covid-19. Dalam kasus covid-19, penelitian yang ada sebelumnya hanya berfokus meneliti determinan prediktor minat vaksin covid-19 menggunakan konsep seperti SelfDetermination Theory dan Willingness to Pay (WTP) (Zampetakis \& Melas, 2021). Sedangkan penelitian ini akan berfokus pada Health Belief Model (HBM). Meskipun HBM pernah digunakan menjadi prediktor dalam penelitian terkait perilaku minat tertentu dalam kesehatan, namun sayangnya masih banyak gap dan sisi kurang jelas lainnya yang menunjukkan perlunya penelitian lebih lanjut (Nancy Chen, 2015). Berdasarkan hal tersebut, maka penelitian ini diharapkan dapat mempersempit atau menjembatani kesenjangan penelitian yang ada. Selain itu, penelitian ini juga diharapkan dapat berkontribusi untuk memperluas dan mengembangkan teori Health Belief Model (HBM), dan pengaruhnya terhadap minat vaksin covid-19.

Dalam model ini, diinterpretasikan bahwa jika seseorang memiliki persepsi kerentanan yang tinggi dan persepsi keparahan terhadap suatu masalah kesehatan, memersepsikan perilaku sasaran memiliki manfaat positif dalam mengurangi munculnya masalah kesehatan, dan memersepsikan hambatan untuk mengadopsi perilaku sasaran yang cukup rendah, ia akan melakukan suatu perilaku kesehatan dan kemudian cenderung mengadopsi perilaku kesehatan tersebut (Sulat et al., 2018). Berdasarkan model tersebut juga, maka hipotesis yang akan diajukan dalam penelitian ini adalah sejumlah empat hipotesis berupa kerentanan yang dirasakan $\left(\mathrm{H}_{1}\right)$, keparahan yang dirasakan $\left(\mathrm{H}_{2}\right)$, manfaat yang dirasakan $\left(\mathrm{H}_{3}\right)$ memiliki pengaruh positif terhadap minat vaksinasi covid-19. Sedangkan hambatan yang dirasakan $\left(\mathrm{H}_{4}\right)$ memiliki pengaruh yang negatif terhadap minat vaksinasi covid-19. Selanjutnya, penelitian ini diharapkan dapat memberikan manfaat bukan hanya pada teori-teori ilmu kesehatan publik dan perilaku sosial, namun juga manfaat praktis yang dapat digunakan oleh pemerintah maupun stakeholder lainnya sebagai pedoman dalam melihat perilaku dan keyakinan masyarakat terkait minat dan penerimaan vaksinasi covid-19 sehingga program vaksinasi dapat secara efektif berjalan secara nasional dan menyeluruh. 
Tabel 1

Karakteristik Responden

\begin{tabular}{llcc}
\hline Identitas Responden & Kategori & Frekuensi & Persentase \\
\hline Jenis Kelamin & Laki-Laki & 254 & $56.19 \%$ \\
\multirow{3}{*}{ Usia } & Perempuan & 198 & $43.81 \%$ \\
& $>11-19$ tahun & 56 & $12.39 \%$ \\
& $20-60$ tahun & 327 & $72.35 \%$ \\
Pekerjaan & $>60$ tahun & 69 & $15.27 \%$ \\
& Pegawai Negeri & 82 & $18.14 \%$ \\
& Pegawai Swasta & 143 & $31.64 \%$ \\
& Wirausaha & 116 & $25.66 \%$ \\
& Pelajar/Mahasiswa & 64 & $14.16 \%$ \\
Status & Tidak Bekerja & 47 & $10.40 \%$ \\
& Non Penyintas covid-19 & 375 & $82.96 \%$ \\
\hline
\end{tabular}

\section{METODE PENELITIAN}

Penelitian ini berusaha menguji dan memprediksi minat vaksinasi covid-19 melalui HBM. Karenanya, penelitian ini tergolong ke dalam penelitian kuantitatif dengan pendekatan yang bersifat cross-sectional. Variabel-variabel dalam penelitian ini berjumlah 5 variabel yang terdiri dari 4 variabel independen dan 1 variabel dependen. Keseluruhan variabel dalam penelitian ini diukur dengan alat ukur atau indikator yang telah dikembangkan dari penelitian sebelumnya yaitu terdiri dari kerentanan yang dirasakan sebanyak 3 indikator dan keparahan yang dirasakan sebanyak 3 indikator yang diadopsi dari Sumaedi et al. (2020). Sedangkan manfaat yang dirasakan diukur dengan 2 indikator, hambatan yang dirasakan dengan 2 indikator, dan minat vaksinasi covid-19 sejumlah 3 indikator yang diadopsi dan dikembangkan dari Paek et al. (2015).

Keseluruhan indikator tersebut berisikan pernyataan yang kemudian dijadikan angket kuesioner untuk disebarkan kepada responden. Responden dalam penelitian ini adalah sampel dari populasi masyarakat Muslim yang berdomisili di Daerah Istimewa Yogyakarta. Alasan memilih lokasi Yogyakarta adalah bahwasanya Yogyakarta merupakan salah satu provinsi dengan kasus covid-19 tertinggi di Indonesia. Karenanya provinsi Yogyakarta juga termasuk ke dalam provinsi yang diprioritaskan dalam vaksinasi massal dari pemerintah (Purbaya, 2021). Setelah melakukan pencarian dan pengambilan sampel selama 3 bulan (Januari 2021 Maret 2021) dengan menggunakan metode purposive sampling, keseluruhan data yang terkumpul adalah sebanyak 466 sampel. Namun 14 harus dieliminasi dikarenakan 11 di antaranya tidak sesuai dengan kriteria yang sudah ditentukan dan 3 di antaranya tidak mengisi kuesioner dengan lengkap sehingga data sampel yang dapat diterima dan akan diproses adalah sebanyak 452 sampel data.

Data sampel tersebut kemudian diproses dan diolah dengan menggunakan metode analisis Partial Least Square Structural Equation Modeling (PLS-SEM). 
Alasan utama menggunakan analisis model ini adalah bahwa penggunaan metode ini akan memungkinkan peneliti untuk memprediksi model yang sangat rumit dengan banyak variabel indikator dan konstruk, terutama ketika tujuan analisis adalah untuk memprediksi. Selain itu, PLS-SEM umumnya memungkinkan banyak fleksibilitas dalam hal persyaratan data serta spesifikasi hubungan antara variabel indikator dan konstruk. Alasan lain adalah aksesibilitas software yang digunakan dengan muda antarmuka pengguna (Sarstedt et al., 2017). Dan dalam penelitian ini, aplikasi perangkat lunak yang digunakan dalam olah data PLS-SEM adalah menggunakan SmartPLS 3.0.

\section{HASIL PENELITIAN}

Berdasarkan tabel 1 yang menunjukkan karakteristik responden, maka dapat disimpulkan bahwa masyarakat Muslim yang berdomisili di Yogyakarta yang menjadi responden dalam penelitian ini adalah mayoritas berjenis kelamin laki-laki $(56.19 \%)$, yang bekerja sebagai pegawai swasta (31.64\%) dengan rentan usia 20 - 60 tahun $(72.35 \%)$ dan belum pernah terinfeksi (non penyintas) covid-19 (82.96\%).

Tabel 2 menunjukkan hasil pengujian model pengukuran dan memperlihatkan bahwa keseluruhan indikator menunjukkan nilai loading yang melebihi 0.7 maka berdasarkan standar dari Avkiran (2018) dan Mehmetoglu (2012), keseluruhan indikator dalam penelitian ini dapat dikatakan reliabel. Selain itu, terlihat juga bahwa nilai Cronbach alpha dan nilai Composite Reliablity (CR) menunjukkan di atas 0.7 , sehingga keseluruhan variabel dalam penelitian ini juga dinilai reliabel. Dalam nilai validitas, harus melihat pada convergent validity degan melihat nilai Average Variance Extracted (AVE) dengan ketentuan nilai AVE harus lebih dari 0.5 dan discriminant validity dengan ketentuan akar kuadrat AVE harus lebih besar daripada korelasi konstruk reflektif dengan semua konstruk lainnya (Avkiran, 2018; Hair et al., 2014; Mehmetoglu, 2012). Maka berdasarkan tabel 2 diperlihatkan bahwa nilai AVE keseluruhan variabel dalam penelitian ini menunjukkan nilai yang melebihi 0.5 , sehingga dari sisi convergent validity, keseluruhan variabel dalam penelitian ini valid. Sedangkan dari sisi discriminant validity ditunjukkan pada tabel 3 bahwa keseluruhan variabel dalam penelitian ini akar kuadrat AVE yang ditunjukkan lebih besar daripada korelasi konstruk reflektif dengan semua konstruk lainnya. Sehingga berdasarkan standar discriminant validity keseluruhan variabel dalam penelitian ini valid.

Pada hasil pengujian model struktural yang ditunjukkan pada tabel 4 bahwa nilai koefisien determinasi $\left(\mathrm{R}^{2}\right)$ yang ditunjukkan adalah sebesar 0.257. Artinya akurasi prediksi model penelitian sebesar $25.7 \%$ diterima namun tingkat akurasi prediksinya masih lemah berdasarkan standar yang ditetapkan oleh (Hair et al., 2014). Meskipun memilik prediksi yang lemah, namun nilai R2 yang rendah tidak selalu menunjukkan bahwa dampaknya kecil dan dapat diabaikan.

Selanjutnya dalam pengujian model struktural adalah melakukan uji besaran 
Tabel 2

Hasil Pengujian Model Pengukuran

\begin{tabular}{|c|c|c|c|c|}
\hline Variabel & Loading & $\alpha$ & $\mathrm{CR}$ & AVE \\
\hline Kerentanan Yang Dirasakan (X1) & & 0.78 & 0.872 & 0.695 \\
\hline Saya sangat rentan tertular covid-19 & 0.844 & & & \\
\hline $\begin{array}{l}\text { Dibandingkan dengan orang lain dalam rentang usia yang } \\
\text { sama, Saya saya lebih rentan tertular covid-19 }\end{array}$ & 0.89 & & & \\
\hline Saya khawatir saya mungkin tertular covid-19 & 0.762 & & & \\
\hline Keparahan Yang Dirasakan (X2) & & 0.79 & 0.878 & 0.708 \\
\hline Bagi saya, covid-19 adalah masalah kesehatan yang parah & 0.902 & & & \\
\hline Covid-19 adalah ancaman serius bagi kesehatan saya & 0.746 & & & \\
\hline Akan sangat buruk jika saya tertular covid-19 & 0.867 & & & \\
\hline Manfaat Yang Dirasakan (X3) & & 0.729 & 0.874 & 0.777 \\
\hline $\begin{array}{l}\text { Vaksinasi sangat bermanfaat karena akan melindungi saya } \\
\text { dari covid-19 }\end{array}$ & 0.94 & & & \\
\hline $\begin{array}{l}\text { Saya yakin vaksinasi covid-19 akan meningkatkan kesehatan } \\
\text { dan tidak berdampak buruk bagi saya }\end{array}$ & 0.819 & & & \\
\hline Hambatan Yang Dirasakan (X4) & & 0.81 & 0.913 & 0.84 \\
\hline $\begin{array}{l}\text { Saya tidak punya cukup waktu untuk memvaksinasi diri saya } \\
\text { sendiri }\end{array}$ & 0.925 & & & \\
\hline Biaya vaksinasi covid-19 menjadi beban bagi saya & 0.908 & & & \\
\hline Minat Vaksinasi covid-19(Y) & & 0.86 & 0.914 & 0.781 \\
\hline $\begin{array}{l}\text { Saya akan memvaksinasi diri saya sendiri dengan vaksin } \\
\text { covid-19 meskipun saya sibuk }\end{array}$ & 0.878 & & & \\
\hline $\begin{array}{l}\text { Saya akan memvaksinasi diri saya sendiri dengan vaksin } \\
\text { covid-19 yang diperlukan }\end{array}$ & 0.886 & & & \\
\hline $\begin{array}{l}\text { Saya akan memvaksinasi diri saya sendiri dengan vaksin } \\
\text { covid-19 yang direkomendasikan pemerintah }\end{array}$ & 0.886 & & & \\
\hline
\end{tabular}

pengaruh antara variabel. Pada tabel 4 ditunjukkan nilai $\mathrm{F}^{2}$ pada pengaruh kerentanan (0.065), keparahan (0.064), manfaat (0.028) dan hambatan (0.022) yang dirasakan terhadap minat vaksinasi covid-19 menunjukkan nilai di antara 0.02 sampai 0.15. Artinya, menurut Hair et al. (2014) bahwa besar pengaruh keseluruhan variabel independen terhadap dependen masih dalam kriteria pengaruh yang kecil.

Tabel 5 menunjukkan hasil pengujian hipotesis yang memperlihatkan bahwa pengaruh kerentanan yang dirasakan $(\beta$ $=0.281 ; p$-value $=0.000)$, keparahan yang dirasakan $(\beta=0.288 ; p$-value $=0.000)$, dan manfaat yang dirasakan $(\beta=0.148 ; p$-value
$=0.001)$ terhadap minat vaksinasi covid-19 menunjukkan hubungan dan pengaruh yang positif dengan nilai signifikansi $p$-value $<$ 0.05. maka dengan demikian $\mathrm{H}_{1} \mathrm{H}_{2}$ dan $\mathrm{H}_{3}$ diterima. Sedangkan pengaruh hambatan yang dirasakan terhadap minat vaksinasi covid-19 menunjukkan hubungan dan pengaruh yang negatif dengan nilai signifikansi $p$-value $<0.05(\beta=-0.146$; $p$-value $=$ $0.008)$. Artinya, $\mathrm{H}_{4}$ dalam penelitian ini juga diterima.

\section{PEMBAHASAN}

\section{Pengaruh Kerentanan Yang Dirasakan Terhadap Minat Vaksinasi Covid-19}

Berdasarkan hasil penelitian di atas 
Tabel 3

Discriminant Validity Fornell-Larcker Criterion

\begin{tabular}{lccccc}
\hline \multicolumn{1}{c}{ Variabel } & 1 & 2 & 3 & 4 & 5 \\
\hline Kerentanan Yang Dirasakan & 0.834 & & & & \\
Keparahan Yang Dirasakan & 0.61 & 0.841 & & & \\
Manfaat Yang Dirasakan & 0.147 & 0.206 & 0.882 & & \\
Hambatan Yang Dirasakan & 0.388 & 0.426 & 0.198 & 0.916 & \\
Minat Vaksinasi covid-19 & 0.422 & 0.427 & 0.22 & 0.115 & 0.884 \\
\hline
\end{tabular}

yang menunjukkan ada pengaruh positif antara kerentanan yang dirasakan terhadap minat vaksinasi covid-19, menjadi bukti bahwa $\mathrm{H}_{1}$ dalam penelitian ini diterima. Hasil penelitian ini sangat selaras dan sejalan dengan hasil penelitian Mo et al. (2019), Guidry et al. (2021), Higuchi et al. (2018), Liao et al. (2016), Myers \& Goodwin (2011), Sundstrom et al. (2015) dan Teitler-Regev et al. (2011) yang membuktikan dalam hasil analisisnya bahwa kerentanan yang dirasakan dikaitkan dengan kemungkinan yang lebih tinggi untuk berminat menerima vaksinasi influenza di masa mendatang. Sekaligus bertentangan dengan hasil penelitian Cavazos-Arroyo \& de Celis-Herrero (2020) yang menemukan pengaruh yang tidak signifikan, Gu et al. (2014) dan Zampetakis \& Melas (2021) yang justru menemukan bahwa minat ditentukan secara negatif oleh persepsi kerentanan dan keparahan serta Kabir et al. (2021) dan Shmueli (2021) tidak menemukan bukti keterkaitan dan hubungan antara konstruksi kerentanan yang dirasakan dan minat vaksinasi covid-19.

Dengan demikian, secara teoritis, minat untuk divaksinasi model teoretis lain yang digunakan dalam Theory Planned Behavior (TPB) yang digunakan untuk memprediksi perilaku individu. Dan menurut model TPB, minat untuk mendapatkan vaksinasi covid-19 tergantung pada sejumlah prediktor yang salah satunya adalah persepsi (Shmueli, 2021). Dengan demikian, persepsi dalam konstruk HBM termasuk ke dalam prediktor minat vaksin. Salah satunya adalah persepsi kerentanan yang mengacu pada keyakinan tentang kerentanan terhadap covid-19 (Lin et al., 2020; Shmueli, 2021). Dalam temuan penelitian ini tampak bahwa persepsi atau kerentanan yang dirasakan berpengaruh positif dan signifikan terhadap minat vaksinasi covid-19. Hal ini tentu mengindikasikan bahwa minat yang tinggi untuk melakukan vaksinasi covid-19 dikaitkan dengan kerentanan yang dirasakan oleh masyarakat Muslim di Yogyakarta. Sehingga ketika masyarakat Muslim di Yogyakar-

\section{Tabel 4}

Hasil Pengujian Model Struktural

\begin{tabular}{cccccc}
\hline & \multicolumn{5}{c}{ Structural Model } \\
\cline { 2 - 5 } $\mathrm{F}^{2}$ & Kerentanan & Keparahan & Manfaat & Hambatan & Minat \\
\cline { 2 - 6 } $\mathrm{R}^{2}$ & 0.065 & 0.064 & 0.028 & 0.022 & 0.257 \\
\hline
\end{tabular}


Tabel 5

Hasil Pengujian Hipotesis

\begin{tabular}{lccc}
\hline \multicolumn{1}{c}{ Hipotesis } & $\beta$ & T Value & $P$-value \\
\hline Kerentanan Yang Dirasakan $\rightarrow$ Minat Vaksinasi covid-19 $\left(\mathrm{H}_{1}\right)$ & 0.281 & 5.329 & 0 \\
Keparahan Yang Dirasakan $\rightarrow$ Minat Vaksinasi covid-19 $\left(\mathrm{H}_{2}\right)$ & 0.288 & 5.3 & 0 \\
Manfaat Yang Dirasakan $\rightarrow$ Minat Vaksinasi covid-19 $\left(\mathrm{H}_{3}\right)$ & 0.148 & 3.481 & 0.001 \\
Hambatan Yang Dirasakan $\rightarrow$ Minat Vaksinasi covid-19 $\left(\mathrm{H}_{4}\right)$ & -0.146 & 2.653 & 0.008 \\
\hline
\end{tabular}

ta memiliki persepsi kerentanan yang tinggi terhadap covid-19, minat mereka untuk melakukan vaksinasipun akan tinggi. Sebaliknya, ketika mereka memiliki persepsi kerentanan yang rendah, maka semakin membuat mereka tidak berminat untuk divaksin covid-19 karena memiliki minat yang rendah.

\section{Pengaruh Keparahan Yang Dirasakan Terhadap Minat Vaksinasi Covid-19}

Selain menunjukkan pengaruh yang positif, keparahan yang dirasakan sekaligus menjadi konstruksi HBM yang paling tinggi dalam mempengaruhi minat jangka panjang untuk menerima vaksin. Artinya, ada pengaruh positif antara keparahan yang dirasakan terhadap minat vaksinasi covid19 yang menjadi bukti bahwa $\mathrm{H}_{2}$ dalam penelitian ini diterima. Hasil penelitian ini sejalan dengan hasil penelitian dari Shahar et al. (2017), Higuchi et al. (2018), Myers \& Goodwin (2011), Sundstrom et al. (2015), dan Teitler-Regev et al. (2011) yang juga menemukan dalam hasil penelitiannya bahwa keparahan yang dirasakan memiliki pengaruh yang positif terhadap minat mendapatkan vaksinasi. Denfan demikian, penelitian ini bertolak belakang dengan hasil penelitian Chin \& Mansori (2019) yang menemukan dampak yang tidak signifikan antara persepsi keparahan terhadap minat perilaku tertentu serta Chen et al. (2011) dan Alobaidi (2021) yang menemukan dalam penelitiannya bahwa keparahan yang dirasakan tidak memainkan peran penting dalam memprediksi minat pasti untuk menerima vaksin.

Hasil temuan penelitian ini dengan demikian sesuai dengan teori analisis HBM yang mengungkapkan bahwa keparahan yang dirasakan terkait dengan minat untuk menerima vaksin. Sehingga individu yang menganggap covid-19 sangat serius lebih mungkin untuk divaksinasi (Kabir et al., 2021). Dengan demikian, Hasil ini mengindikasikan bahwa tinggi dan rendahnya minat untuk melakukan vaksinasi covid-19 berkaitan erat dengan tinggi dan rendahnya keparahan yang dirasakan oleh masyarakat Muslim di Yogyakarta. Sehingga ketika masyarakat Muslim di Yogyakarta memiliki persepsi keparahan yang tinggi terhadap covid-19, minat mereka untuk melakukan vaksinasi pun akan tinggi. Sebaliknya, ketika mereka memiliki persepsi keparahan yang rendah, maka semakin membuat mereka tidak berminat untuk divaksin covid-19 karena memiliki minat yang rendah.

\section{Pengaruh Manfaat Yang Dirasakan Ter- hadap Minat Vaksinasi Covid-19}

Pengaruh positif antara manfaat 
yang dirasakan terhadap minat vaksinasi covid-19 telah menjadi bukti bahwa $\mathrm{H}_{3}$ dalam penelitian ini diterima. Hasil penelitian ini tentu bertolak belakang dengan hasil penelitian dari Lee (2021) namun tetap sejalan dengan hasil penelitian dari Shahar et al. (2017) Guidry et al. (2021), Lin et al. (2020), Mo et al. (2019), Sundstrom et al. (2015) dan Wong et al. (2020) yang dalam penelitiannya membuktikan pengaruh positif signifikan yang kuat ditemukan antara manfaat yang dirasakan dari menerima vaksin dan minat untuk menerima vaksin sekaligus menjadi konstruksi Model Keyakinan Kesehatan yang paling signifikan yang mempengaruhi minat jangka panjang untuk menerima vaksin.

Berdasarkan hal tersebut, sehubungan dengan vaksinasi, manfaat yang dirasakan didefinisikan sebagai keyakinan positif individu tentang vaksinasi (Lin et al., 2020; Shmueli, 2021) yang dalam kerangka teori HBM diposisikan dalam perilaku kesehatan tertentu sebagai prediktor utama minat untuk terlibat dalam perilaku tertentu (Kerr et al., 2021). Dengan demikian, penelitian ini juga menginterpretasikan bahwa manfaat yang dirasakan terhadap minat untuk menerima vaksin berkonsekuensi bahwa semakin tinggi manfaat menerima vaksin menurut masyarakat Muslim di Yogyakarta, semakin tinggi minat mereka untuk menerima vaksin. Begitupun sebaliknya, semakin rendah manfaat yang dirasakan, maka semakin rendah pula minat mereka untuk mendapatkan vaksinasi covid-19. Ini merupakan temuan penting bagi pejabat kesehatan karena ini menunjukkan bahwa mungkin metode yang paling bermanfaat untuk mempengaruhi penerimaan vaksin adalah dengan mensosialisasikan tentang manfaatnya (Ratnapradipa et al., 2017).

\section{Pengaruh Hambatan Yang Dirasakan Terhadap Minat Vaksinasi Covid-19}

Terakhir, pengaruh negatif antara hambatan yang dirasakan terhadap minat vaksinasi covid-19 yang menjadi bukti bahwa $\mathrm{H}_{4}$ dalam penelitian ini diterima. Hasil penelitian ini bertentangan dengan hasil penelitian dari Mercadante \& Law (2021) yang menemukan dalam bahwa hambatan yang dirasakan mempengaruhi dan memprediksi minat vaksin juga bertentangan dengan Cheney \& John (2013) yang menemukan bahwa hambatan yang dirasakan secara signifikan terkait dengan minat untuk divaksinasi, bahkan responden yang melaporkan hambatan untuk mengakses vaksinasi memiliki kemungkinan 7,5 kali lipat berencana untuk divaksinasi. Meskipun demikian, hasil penelitian ini tetap sejalan dengan hasil penelitian dari Shahar et al. (2017), Guidry et al. (2021), Mo et al. (2019), Sundstrom et al. (2015), dan Teitler -Regev et al. (2011) yang juga menemukan dalam hasil penelitiannya bahwa ada pengaruh negatif yang cukup signifikan ditemukan antara persepsi hambatan untuk menerima vaksin dan minat untuk menerima vaksin.

Dalam teori HBM, hambatan yang dirasakan digambarkan sebagai keyakinan bahwa divaksinasi dibatasi karena faktor waktu dan keuangan (Lin et al., 2020; Shmueli, 2021). Persepsi ini kemudian dipercaya mempengaruhi perilaku vaksinasi individu yang dalam hal ini dengan 
pengaruh yang negatif (Huynh et al., 2021). Berdasarkan hal tersebut, maka hasil ini berkonsekuensi bahwa semakin tinggi hambatan (dari sisi waktu maupun keuangan) dalam menerima vaksin, justru membuat minat masyarakat Muslim di Yogyakarta semakin rendah untuk menerima vaksin covid-19. Sebaliknya, semakin rendah hambatan dalam menerima vaksin yang dirasakan oleh masyarakat Muslim di Yogyakarta, semakin tinggi minat mereka untuk menerima vaksin.

Dengan diterimanya semua hipotesis dalam penelitian ini, maka dengan demikian penelitian ini telah berhasil dalam memberikan model teoritis dari HBM yang mencakup variabel seperti kerentanan, keparahan, manfaat, dan hambatan yang dirasakan yang sejak lama sudah diakui dapat memprediksi minat perilaku, yang pada gilirannya, akan memprediksi perilaku (Gerend \& Shepherd, 2012; Sundstrom et al., 2018). Karena berdasarkan TPB, suatu perilaku didorong oleh minat untuk melakukan perilaku tersebut, yang pada akhirnya ditentukan oleh "struktur keyakinan" individu. Sebagaimana diterapkan pada konteks vaksin covid-19, struktur keyakinan terdiri dari kerentanan, keparahan, manfaat, dan hambatan yang dirasakan terhadap covid-19 (Hossain et al., 2021). Selain itu, Temuan penelitian ini juga menggarisbawahi pentingnya menyiapkan rencana intervensi untuk menangani responden dalam menerima vaksin dan memastikan penyerapan vaksinasi covid-19, baik bagi kelompok berisiko tinggi maupun kelompok berisiko rendah. Di sisi lain, penelitian ini juga sekaligus memberikan titik awal untuk penelitian minat vaksinasi covid-19 di Indonesia.

\section{KESIMPULAN}

Berdasarkan penelitian terkait HBM dan minat vaksinasi covid-19 ini, hasil dalam penelitian ini menyimpulkan bahwa masyarakat Muslim Yogyakarta yang menerima vaksinasi covid-19 lebih cenderung memiliki persepsi bahwa covid-19 sebagai ancaman yang serius bagi kesehatan mereka dengan menganggap bahwa mereka merasa diri mereka sangat rentan terkena covid-19 dan covid-19 adalah penyakit yang parah atau serius. Selain itu, manfaat yang dirasakan dari vaksinasi covid-19 juga menjadi prediktor yang membuat mereka berminat untuk menerima vaksinasi covid-19. Namun di sisi lain, hambatan akses adalah masalah yang secara negatif mempengaruhi perilaku minat vaksinasi mereka.

Melihat bahwa hasil dari penelitian ini mengindikasikan adanya hubungan yang kuat antara minat untuk vaksinsasi covid-19 dengan HBM maka perlu bagi Pemerintah Daerah hingga Pusat untuk memahami bahwa persepsi masyarakat tentang kerentanan, keparahan, manfaat, dan hambatan sehingga dapat memberikan peluang untuk mengembangkan kampanye yang efektif terhadap program vaksinasi massal yang sedang diprogramkan oleh pemerintah demi memutus mata rantai dari penyebaran covid-19 yang lebih masif lagi. Meskipun demikian, penelitian ini masih memiliki kekurangan yang hanya menargetkan masyarakat Muslim yang berdomisili di Yogyakarta saja. Artinya hasil pada penelitian ini tidak bisa digeneralisir secara umum bagi masyarakat Indonesia secara keseluruhan. Sehingga, 
penelitian lebih lanjut dengan melibatkan sampel yang lebih banyak lagi dengan tempat penelitian yang lebih luas lagi sangat diperlukan bagi peneliti selanjutnya demi mendapatkan data dan kesimpulan yang lebih baik lagi. Selain itu, penelitian ini juga melibatkan responden penyintas covid19 dan non penyintas yang kemungkinan besar memiliki persepsi yang berbeda. Sehingga penelitian selanjutnya sangat direkomendasikan dapat melakukan penelitian terpisah terhadap masing-masing status pengalaman responden terhadap covid-19 demi hasil yang lebih baik dan kredibel.

\section{DAFTAR PUSTAKA}

Alhalaseh, L., Fayoumi, H., \& Khalil, B. (2020). The Health Belief Model in Predicting Healthcare Workers' Intention for Influenza Vaccine Uptake in Jordan. Vaccine, 38(46), 7372-7378. https://doi.org/10.1016/ j.vaccine.2020.09.002

Alobaidi, S. (2021). Predictors of Intent to Receive the COVID-19 Vaccination Among the Population in the Kingdom of Saudi Arabia: A Survey Study. Journal of Multidisciplinary Healthcare, Volume 14, 1119-1128. https:// doi.org/10.2147/jmdh.s306654

Araban, M., Baharzadeh, K., \& Karimy, M. (2017). Nutrition Modification Aimed at Enhancing Dietary Iron and Folic Acid Intake: An Application of Health Belief Model in Practice. European Journal of Public Health, 27(2), 287-292. https://doi.org/10.1093/eurpub/ ckw238

Auslander, B. A., Meers, J. M., Short, M. B., Zimet, G. D., \& Rosenthal, S. L. (2019). A Qualitative Analysis of The Vaccine IntentionBehaviour Relationship: Parents' Descriptions of Their Intentions, Decision-Making Behaviour and Planning Processes Towards HPV Vaccination. Psychology and Health, 34(3), 271-288.

doi.org/10.1080/08870446.2018.1523408

Avkiran, N. K. (2018). Rise of the partial least squares structural equation modeling: An application in banking. In International Series in
Operations Research and Management Science (Vol. 267, pp. 1-29). Springer New York LLC. https://doi.org/10.1007/978-3-31971691-6 1

Bennet, B. M., Wolf, J., Laureano, R., \& Sellers, R. S. (2020). Review of Current Vaccine Development Strategies to Prevent Coronavirus Disease 2019 (covid-19). Toxicologic Pathology, 48(7), 800-809. https:// doi.org/10.1177/0192623320959090

Cahyadi, H. S., \& Newsome, D. (2021). The Post COVID-19 Tourism Dilemma for Geoparks in Indonesia. International Journal of Geoheritage and Parks. https://doi.org/10.1016/ j.ijgeop.2021.02.003

Cavazos-Arroyo, J., \& de Celis-Herrero, C. P. (2020). Severity, susceptibility and social norms perceived as antecedents of the intention to be vaccinated against covid-19. Revista de Salud Publica, 22(2), 1-7. https:// doi.org/10.15446/rsap.v22n2.86877

Centers for Disease Control and Prevention. (2021, May). Covid-19 Vaccines for Children and Teens | CDC. https://www.cdc.gov/ coronavirus/2019-ncov/vaccines/ recommendations/adolescents.html

Chen, M. F., Wang, R. H., Schneider, J. K., Tsai, C. T., Dah-Shyong Jiang, D., Hung, M. N., \& Lin, L. J. (2011). Using the health belief model to understand caregiver factors influencing childhood influenza vaccinations. Journal of Community Health Nursing, 28(1), 29-40. https:// doi.org/10.1080/07370016.2011.539087

Cheney, M. K., \& John, R. (2013). Underutilization of influenza vaccine: A test of the Health Belief Model. SAGE Open, 3(2), 1-12. https:// doi.org/10.1177/2158244013484732

Chin, J. H., \& Mansori, S. (2019). Theory of Planned Behaviour and Health Belief Model: Females' Intention on Breast Cancer Screening. Cogent Psychology, 6(1), 1647927. https:// doi.org/10.1080/23311908.2019.1647927

Committee on Infectious Diseases. (2021). COVID19 Vaccines in Children and Adolescents. Pediatrics: Official Journal of American Academy of Pediatrics, 1-7. https:// doi.org/10.1542/peds.2021-052336

Dinleyici, E. C., Borrow, R., Safadi, M. A. P., van Damme, P., \& Munoz, F. M. (2021). Vaccines 
and Routine Immunization Strategies During The covid-19 Pandemic. Human Vaccines \& Immunotherapeutics, 17(2), 400-407. https:// doi.org/10.1080/21645515.2020.1804776

European Medicines Agency. (2021, May). First covid-19 vaccine approved for children aged 12 to 15 in EU. https://www.ema.europa.eu/en/ news/first-covid-19-vaccine-approved-children -aged-12-15-eu

Fathian-Dastgerdi, Z., Khoshgoftar, M., Tavakoli, B., \& Jaleh, M. (2021). Factors Associated With Preventive Behaviors of covid-19 Among Adolescents: Applying The Health Belief Model. Research in Social and Administrative Pharmacy, 1-5. https://doi.org/10.1016/ j.sapharm.2021.01.014

Fogel, J., \& Kusz, M. (2016). Intentions to Receive a Potentially Available Lyme Disease Vaccine in an Urban Sample. Therapeutic Advances in Vaccines, 4(1-2), 3-14. https:// doi.org/10.1177/2051013616629881

Gerend, M. A., \& Shepherd, J. E. (2012). Predicting human papillomavirus vaccine uptake in young adult women: Comparing the health belief model and theory of planned behavior. Annals of Behavioral Medicine, 44(2), 171-180. https://doi.org/10.1007/s12160-012-9366-5

Gu, Y., Li, L., Zhou, C., Yang, T., \& Dong, H. (2014). Factors influencing voluntary premarital medical examination in Zhejiang province, China: A culturally-tailored health behavioral model analysis. BMC Public Health, 14(1), 659. https://doi.org/10.1186/1471-2458-14-659

Guan, W., Ni, Z., Hu, Y., Liang, W., Ou, C., He, J., Liu, L., Shan, H., Lei, C., Hui, D. S. C., Du, B., Li, L., Zeng, G., Yuen, K.-Y., Chen, R., Tang, C., Wang, T., Chen, P., Xiang, J., ... Zhong, N. (2020). Clinical Characteristics of Coronavirus Disease 2019 in China. New England Journal of Medicine, 382(18), 17081720 .

NEJMoa2002032

Guidry, J. P. D., Laestadius, L. I., Vraga, E. K., Miller, C. A., Perrin, P. B., Burton, C. W., Ryan, M., Fuemmeler, B. F., \& Carlyle, K. E. (2021). Willingness to get the covid-19 vaccine with and without emergency use authorization. American Journal of Infection Control, 49(2), 137-142. https://doi.org/10.1016/ j.ajic. 2020.11 .018

Gurwith, M., Condit, R. C., Excler, J. L., Robertson,
J. S., Kim, D., Fast, P. E., Drew, S., Wood, D., Klug, B., Whelan, M., Mallett Moore, T., Khuri-Bulos, N., Smith, E. R., Chen, R. T., \& Kochhar, S. (2020). Brighton Collaboration Viral Vector Vaccines Safety Working Group (V3SWG) standardized template for collection of key information for benefit-risk assessment of live-attenuated viral vaccines. In Vaccine (Vol. 38, Issue 49, pp. 7702-7707). Elsevier Ltd. https://doi.org/10.1016/ j.vaccine.2020.09.042

Hair, J. F., Sarstedt, M., Hopkins, L., \& Kuppelwieser, V. G. (2014). Partial least squares structural equation modeling (PLS-SEM): An emerging tool in business research. In European Business Review (Vol. 26, Issue 2, pp. 106121). Emerald Group Publishing Ltd. https:// doi.org/10.1108/EBR-10-2013-0128

Harismi, A. (2020). Klasifikasi Umur Menurut WHO dan Masalah Kesehatannya.

Higuchi, M., Narumoto, K., Goto, T., \& Inoue, M. (2018). Correlation between family physician's direct advice and pneumococcal vaccination intention and behavior among the elderly in Japan: a cross-sectional study. BMC Family Practice, 19(1), 153. https://doi.org/10.1186/ s12875-018-0841-3

Hodgson, S. H., Mansatta, K., Mallett, G., Harris, V., Emary, K. R. W., \& Pollard, A. J. (2021). What defines an efficacious covid-19 vaccine? A review of the challenges assessing the clinical efficacy of vaccines against SARS-CoV-2. The Lancet Infectious Diseases, 21(2), e26e35. https://doi.org/10.1016/S1473-3099(20) 30773-8

Hossain, M. B., Alam, M. Z., Islam, M. S., Sultan, S., Faysal, M. M., Rima, S., Hossain, M. A., \& Mamun, A. Al. (2021). Health Belief, Planned Behavior, or Psychological Antecedents: What predicts COVID-19 Vaccine Hesitancy better among the Bangladeshi Adults? MedRxiv, 2021.04.19.21255578. https:// doi.org/10.1101/2021.04.19.21255578

Huynh, G., Nguyen, T. Van, Nguyen, D. D., Lam, Q. M., Pham, T. N., \& Nguyen, H. T. N. (2021). Knowledge About COVID-19, Beliefs and Vaccination Acceptance Against covid-19 Among High-Risk People in Ho Chi Minh City, Vietnam. Infection and Drug Resistance, Volume 14, 1773-1780. https:// doi.org/10.2147/idr.s308446

Kabir, R., Mahmud, I., Chowdhury, M. T. H., Vinna- 
kota, D., Jahan, S. S., Siddika, N., Isha, S. N., Nath, S. K., \& Apu, E. H. (2021). Covid-19 vaccination intent and willingness to pay in Bangladesh: A cross-sectional study. Vaccines, 9(5), $416 . \quad$ https://doi.org/10.3390/ vaccines 9050416

Karafillakis, E., \& Larson, H. J. (2017). The benefit of the doubt or doubts over benefits? A systematic literature review of perceived risks of vaccines in European populations. In Vaccine (Vol. 35, Issue 37, pp. 4840-4850). Elsevier Ltd. j.vaccine.2017.07.061 https://doi.org/10.1016/

Karlsson, L. C., Soveri, A., Lewandowsky, S., Karlsson, L., Karlsson, H., Nolvi, S., Karukivi, M., Lindfelt, M., \& Antfolk, J. (2021). Fearing The Disease or The Vaccine: The Case of covid-19. Personality and Individual Differences, 172. https://doi.org/10.1016/j.paid.2020.110590

Kerr, J. R., Freeman, A. L. J., Marteau, T. M., \& van der Linden, S. (2021). Effect of information about COVID-19 vaccine effectiveness and side effects on behavioural intentions: Two online experiments. Vaccines, 9(4), 379. https://doi.org/10.3390/vaccines9040379

Kusumaningrum, S., Siagian, C., \& Beazley, H. (2021). Children during the covid-19 pandemic: children and young people's vulnerability and wellbeing in Indonesia. Children's Geographies. https:// doi.org/10.1080/14733285.2021.1900544

Lee, J.-W. (2021). Covid-19 Preventive action Intention Determinants-Focused on the Expanded Health Belief Model. In Annals of the Romanian Society for Cell Biology (Vol. 25).

Liao, Q., Lam, W. W. T., Cowling, B. J., \& Fielding, R. (2016). Psychosocial Influences on Parental Decision-Making Regarding Vaccination Against Seasonal Influenza for Young Children in Hong Kong: a Longitudinal Study, 2012-2013. International Journal of Behavioral Medicine, 23(5), 621-634. https:// doi.org/10.1007/s12529-016-9551-1

Lin, Y., Hu, Z., Zhao, Q., Alias, H., Danaee, M., \& Wong, L. P. (2020). Understanding COVID-19 vaccine demand and hesitancy: A nationwide online survey in China. PLOS Neglected Tropical Diseases, 14(12), e0008961. https:// doi.org/10.1371/journal.pntd.0008961

Liu, Z., \& Yang, J. Z. (2020). In the Wake of Scandals: How Media Use and Social Trust Influ- ence Risk Perception and Vaccination Intention among Chinese Parents. Health Communication, 1-12. https:// doi.org/10.1080/10410236.2020.1748834

Lytras, T., \& Tsiodras, S. (2021). Lockdowns and the COVID-19 pandemic: What is the endgame? Scandinavian Journal of Public Health, 49(1), 37-40. https:// doi.org/10.1177/1403494820961293

Mehmetoglu, M. (2012). Partial least squares approach to structural equation modeling for tourism research. Advances in Hospitality and Leisure, 8, 43-61. https://doi.org/10.1108/ S1745-3542(2012)0000008007

Mercadante, A. R., \& Law, A. V. (2021). Will they, or Won't they? Examining patients' vaccine intention for flu and covid-19 using the Health Belief Model. Research in Social and Administrative Pharmacy. https://doi.org/10.1016/ j.sapharm.2020.12.012

Mo, P. K. H., Wong, C. H. W., \& Lam, E. H. K. (2019). Can the Health Belief Model and moral responsibility explain influenza vaccination uptake among nurses? Journal of Advanced Nursing, 75(6), 1188-1206. https:// doi.org/10.1111/jan.13894

Moksony, F. (1990). Small is beautiful. The use and interpretation of R2 in social research. Szociológiai Szemle, 130-138.

Myers, L. B., \& Goodwin, R. (2011). Determinants of adults' intention to vaccinate against pandemic swine flu. BMC Public Health, 11(1), 15. https://doi.org/10.1186/1471-2458-11-15

Nancy Chen, N. T. (2015). Predicting Vaccination Intention and Benefit and Risk Perceptions: The Incorporation of Affect, Trust, and Television Influence in a Dual-Mode Model. Risk Analysis, 35(7), 1268-1280. https:// doi.org/10.1111/risa. 12348

Olagoke, A. A., Olagoke, O. O., \& Hughes, A. M. (2021). Intention to Vaccinate Against the Novel 2019 Coronavirus Disease: The Role of Health Locus of Control and Religiosity. Journal of Religion and Health, 60(1), 65-80. https://doi.org/10.1007/s10943-020-01090-9

Paek, H. J., Shin, K. A., \& Park, K. (2015). Determinants of caregivers' vaccination intention with respect to child age group: A cross-sectional survey in South Korea. BMJ Open, 5(9), e008342. https://doi.org/10.1136/bmjopen2015-008342 
Pascawati, N. A., \& Satoto, T. B. T. (2020). Public knowledge, attitudes and practices towards COVID-19. International Journal of Public Health Science (IJPHS), 9(4), 292-302. https://doi.org/10.11591/ijphs.v9i4.20539

Paul, E., Steptoe, A., \& Fancourt, D. (2021). Attitudes towards vaccines and intention to vaccinate against COVID-19: Implications for public health communications. The Lancet Regional Health - Europe, 1, 100012. https:// doi.org/10.1016/j.lanepe.2020.100012

Pradana, M., Rubiyanti, N., S, W., Hasbi, I., \& Utami, D. G. (2020). Indonesia's Fight Against COVID-19: The Roles of Local Government Units and Community Organisations. Local Environment, 25(9), 741-743. https:// doi.org/10.1080/13549839.2020.1811960

Purbaya, A. A. (2021, January 13). 5 Daerah di Jateng-DIY Prioritas Vaksinasi dengan Berbagai Pertimbangan. https:// news.detik.com/berita-jawa-tengah/d5331688/5-daerah-di-jateng-diy-prioritasvaksinasi-dengan-berbagai-pertimbangan

Ratnapradipa, K. L., Norrenberns, R., Turner, J. A., \& Kunerth, A. (2017). Freshman Flu Vaccination Behavior and Intention During a Nonpandemic Season. Health Promotion Practice, 18 (5), 662-671. https:// doi.org/10.1177/1524839917712731

Rohadi, M. R., Priyanto, B., Wardhana, D. P. W., Prihastomo, K. T., \& Kamil, M. (2020). covid19 and its Impact on Neurosurgery: Our Early Experience in Lombok Island Indonesia. In Interdisciplinary Neurosurgery: Advanced Techniques and Case Management (Vol. 22). Elsevier B.V. https://doi.org/10.1016/ j.inat.2020.100868

Sarstedt, M., Ringle, C. M., \& Hair, J. F. (2017). Partial Least Squares Structural Equation Modeling. In Handbook of Market Research (pp. 140). Springer International Publishing. https:// doi.org/10.1007/978-3-319-05542-8_15-1

Sengupta, S., \& Wang, H. M. D. (2014). Information sources and adoption of vaccine during pandemics. International Journal of Pharmaceutical and Healthcare Marketing, 8(4), 357-370. https://doi.org/10.1108/IJPHM-01-2014-0002

Shahar, I., Mendelson, G., \& Ben Natan, M. (2017). Intention to receive the seasonal influenza vaccine among nurses working in a long-term care facility. International Journal of Nursing
Practice, 23(2), e12512. https:// doi.org/10.1111/ijn. 12512

Shahrabani, S., \& Benzion, U. (2012). How Experience Shapes Health Beliefs: The Case of Influenza Vaccination. Health Education and Behavior, 39(5), 612-619. https:// doi.org/10.1177/1090198111427411

Shmueli, L. (2021). Predicting intention to receive covid-19 vaccine among the general population using the health belief model and the theory of planned behavior model. BMC Public Health, 21(1), 1-13. https://doi.org/10.1186/ s12889-021-10816-7

Sparrow, R., Dartanto, T., \& Hartwig, R. (2020). Indonesia Under the New Normal: Challenges and the Way Ahead. Bulletin of Indonesian Economic Studies, 56(3), 269-299. https:// doi.org/10.1080/00074918.2020.1854079

Sulat, J. S., Prabandari, Y. S., Sanusi, R., Hapsari, E. D., \& Santoso, B. (2018). The Validity of Health Belief Model Variables in Predicting Behavioral Change: A Scoping Review. In Health Education (Vol. 118, Issue 6, pp. 499512). Emerald Group Publishing Ltd. https:// doi.org/10.1108/HE-05-2018-0027

Sumaedi, S., Bakti, I. G. M. Y., Rakhmawati, T., Widianti, T., Astrini, N. J., Damayanti, S., Massijaya, M. A., \& Jati, R. K. (2020). Factors influencing intention to follow the "stay at home" policy during the covid-19 pandemic. International Journal of Health Governance, 26(1), 13-27. https://doi.org/10.1108/IJHG-052020-0046

Sundstrom, B., Brandt, H. M., Gray, L., \& Young Pierce, J. (2018). It's My Time: Applying The Health Belief Model to Prevent Cervical Cancer Among College-Age Women. Journal of Communication Management, 22(2), 161-178. https://doi.org/10.1108/JCOM-06-2016-0044

Sundstrom, B., Carr, L. A., DeMaria, A. L., Korte, J. E., Modesitt, S. C., \& Pierce, J. Y. (2015). Protecting the Next Generation: Elaborating the Health Belief Model to Increase HPV Vaccination Among College-Age Women. Social Marketing Quarterly, 21(3), 173-188. https:// doi.org/10.1177/1524500415598984

Suwantika, A. A., Boersma, C., \& Postma, M. J. (2020). The Potential Impact of covid-19 Pandemic on The Immunization Performance in Indonesia. Expert Review of Vaccines, 19(8), 687-690. https:// doi.org/10.1080/14760584.2020.1800461 
Teitler-Regev, S., Shahrabani, S., \& Benzion, U. (2011). Factors Affecting Intention among Students to Be Vaccinated against $\mathrm{A} / \mathrm{H} 1 \mathrm{~N} 1$ Influenza: A Health Belief Model Approach. Advances in Preventive Medicine, 2011, 1-8. https://doi.org/10.4061/2011/353207

Urias, E. (2017). The contribution of the pharmaceutical industry to the health status of the developing world. In International Business and Management (Vol. 33, pp. 41-67). Emerald Group Publishing Ltd. https://doi.org/10.1108/ S1876-066X20170000033003

Velavan, T. P., Pollard, A. J., \& Kremsner, P. G. (2020). Herd immunity and vaccination of children for COVID-19. International Journal of Infectious Diseases, 98, 14-15. https:// doi.org/10.1016/j.ijid.2020.06.065
Wong, L. P., Alias, H., Wong, P. F., Lee, H. Y., \& AbuBakar, S. (2020). The use of the health belief model to assess predictors of intent to receive the covid-19 vaccine and willingness to pay. Human Vaccines and Immunotherapeutics, 16(9), 2204-2214. https:// doi.org/10.1080/21645515.2020.1790279

Zampetakis, L. A., \& Melas, C. (2021). The health belief model predicts vaccination intentions against covid-19: A survey experiment approach. Applied Psychology: Health and WellBeing, 13(2), 469-484. https://doi.org/10.1111/ aphw. 12262

Zhang, Y., \& Fisk, R. J. (2021). Barriers to vaccination for coronavirus disease 2019 (covid-19) control: experience from the United States. Global Health Journal, 5(1), 51-55. https:// doi.org/10.1016/j.glohj.2021.02.005 